\title{
Public service employment restructuring in the crisis in the UK and Ireland: Social partnership in retreat
}

Stephen Bach

Alexandra Stroleny

Corresponding Author:

Stephen Bach, King's College, Franklin-Wilkins Building, London SE1 9NH, UK. Email: stephen.bach@kcl.ac.uk

\begin{abstract}
The crisis has had major consequences for public service employment relations in the liberal market economies of the UK and Ireland. However, variations in the process of fiscal consolidation reflect different legacies of social partnership, prior patterns of public management reform and different relationships to the eurozone. The measures adopted nevertheless reflect a similar concern to decrease public sector employment, worsen pay and conditions and increase work effort. Despite the deterioration of terms and conditions of employment, industrial action has been muted, reflecting the severe weakness of trade unions. Both cases illustrate that governments have become less concerned to gain trade union support to push through austerity measures.
\end{abstract}

Keywords Austerity, industrial action, Ireland, social partnership, UK

One of the most pronounced consequences of the crisis in Europe from 2008 onwards has been to place public services in the vanguard of fiscal consolidation. In the UK and Ireland there has been a particularly sharp disjuncture between the origins of the crisis in the excesses of the financial sector and the burden of adjustment that has fallen on the public sector. In contrast to the experience of Greece, Portugal and Spain there has been limited protest and few public sector strikes (Bach and Pedersini, 2013). Ireland had to seek a financial bail-out, involving external supervision of their plans to achieve fiscal balance, whilst the UK's austerity measures were more self-imposed. In Ireland, the government has sought legitimacy for austerity measures through successive collective agreements with trade unions on pay and employment matters, in contrast to unilateral government imposition of pay restraint in the UK. The measures adopted, however, have been comparable, concentrating on paybill reductions by shrinking employment, worsening pay and conditions and requiring increased effort via longer working hours and tighter performance management.

Ireland and the UK are invariably categorized as liberal, Anglo-Saxon, models of capitalism. The corporate governance literature implies that austerity measures will be implemented with less recourse to employee participation in liberal market economies with less institutionalized systems of employee representation than in coordinated market economies. Nonetheless, there is increased recognition that such typologies capture inadequately the variations between 
countries within the same category; there may be varieties of liberalism (Konzelmann and Vargue-Davies, 2013). Before the crisis, Ireland was central to debates on the institutional preconditions for social partnership. Commentators were puzzled by the establishment from 1987 onwards of a series of three-year national economic and social agreements that contributed to a highly centralized and coordinated approach to wage determination, even though few of the usual institutional preconditions for social partnership appeared to be present (Roche, 2007). For sceptics, the onset of the crisis seemed to confirm the fragility of the Irish social partnership model, which unravelled during 2009, indicating that social partnership was not embedded in the liberalized Irish system and that the scale of adjustments precluded social partnership (Regan, 2012).

Ireland and the UK share a broadly voluntarist industrial relations tradition and similar models of public sector employment regulation. In the UK, collective bargaining and trade union membership have been the norm, with few restrictions on strike action in the public sector. Pay determination remains predominantly centralized, despite some devolution, with sectoral collective bargaining in large bargaining units supplemented by a process of pay review (Perkins and White, 2010). Ireland also has a voluntarist tradition underpinned by state dispute resolution institutions. Traditionally, the three main branches of the public sector - the civil service, health and local authorities - were covered by a single national agreement, although each sector has different pay structures and some devolution has occurred.

We compare and contrast the consequences for public services in both countries of fiscal consolidation, and the extent to which the social partners have been involved in shaping and implementing austerity measures. We first examine the economic context and the prior legacy of public sector reform, before considering austerity measures that relate to pay and pensions. We highlight the impact on employment before assessing the implications for social partnership and public sector trade unionism.

\section{Economic crisis: Shrinking the state}

Ireland and the UK were tethered to a specific form of finance-led capitalism that made both countries especially vulnerable to the crisis, albeit to varying degrees. The crisis was evident at an early stage, with a banking collapse, economic recession and a severe increase in unemployment, again more evident in the case of Ireland. These shocks precipitated a sharp increase in government expenditure and a worsening debt position (Wahrig and Vallina, 2012).

Ireland had less flexibility than the UK to adjust to the crisis because of its membership of the eurozone. The premise of Economic and Monetary Union is that without the option of currency devaluation, governments will have to improve competitiveness by 'internal devaluation', reducing the public sector paybill. Internal devaluation poses considerable risks of industrial relations conflict and electoral backlash. During previous economic crises the Irish government aimed to bolster competitiveness by an orderly process of national social partnership agreements (Regan, 2012). In the UK there is no tradition of social partnership, and public sector trade unions have had limited involvement with public policy, but the 1997-2010 Labour 
government took tentative steps to engage them in workforce modernization. Labour government policies of privatization were recalibrated because of trade union pressure, but this influence was exerted mainly through traditional political channels (contacts with government ministers) rather than through fragile social partnership forums established in the NHS and elsewhere (Bach, 2002; Bach and Kessler, 2012).

The current crisis has proved more intractable because in rescuing its banking sector, the Irish state controversially provided a blanket guarantee that it would cover the assets and liabilities of its domestic banks (Allen, 2012; Kerrigan, 2012). Ireland required $€ 85$ billion in November 2010 under the European Financial Stability Mechanism and this financial assistance is monitored closely by the Troika, resulting in a loss of economic sovereignty. The Irish government moved swiftly to embrace austerity measures from late 2008, aiming to reduce the deficit as a proportion of GDP to below three percent by 2015. This entails almost $€ 22$ billion of expenditure cuts between 2008 and 2015 and around $€ 12$ billion of tax increases, so approximately two-thirds of savings involve expenditure reductions (FitzGerald, 2012).

The UK fiscal context was less critical, but the Conservative-led coalition government in office since 2010 also pursued an aggressive policy of fiscal consolidation. Austerity measures stemmed from its own ideological predilections, but also to advance patterns of public sector reform pursued vigorously by the previous Labour government. The coalition agreement stated that 'deficit reduction and continuing to ensure economic recovery, is the most urgent issue facing Britain' (Cabinet Office, 2010: 15). This statement resonates strongly with the assertion by the Thatcher Conservative government that 'Public expenditure is at the heart of Britain's present economic difficulties' (HM Treasury, 1979: 1). In 2010, public opinion seemed to support the government's argument that spending cuts were necessary to shrink national debt, but support declined from 58 percent to 46 percent by June 2012 (Ipsos Mori, 2012).

This ideology has been translated into an exceptionally large and rapid fiscal consolidation programme. The 2010 Comprehensive Spending Review aimed to reduce the deficit from 8.4 percent of GDP in 2009 to 0.4 percent by 2015, with three quarters of the deficit reduction linked to public spending cuts. By $2015, £ 80.5$ billion cuts in public expenditure are planned (Treasury, 2010a, 2010b), amounting to the tightest sustained period for public services spending since 1945. Over the period April 2010-March 2017 there would be a cumulative real-terms cut of 16.2 percent, almost twice the magnitude of the 8.7 percent cut imposed between 1975 and 1982 (Institute for Fiscal Studies, 2012). Local government has been especially hard hit, required to reduce spending by 27 percent in real terms between 2010-2011 and 2014-2015, whilst National Health Service (NHS) expenditure will be flat in real terms.

\section{Austerity measures in a context of public sector reform}

The UK has long been in the vanguard of attempts to implement 'new public management' (NPM) reforms, marketizing public services and encouraging private contractors; strengthening managerial prerogatives and applying targets to strengthen performance management. One consequence of these changes is that managerial authority within public 
services has been strengthened markedly, blunting the scope for public services professionals and workforce representatives to curtail central government policy measures (Bach and Kessler, 2012).

The main focus of austerity measures has been on quantitative reductions in employment and wages, but the coalition has also pursued structural reforms of public sector organization that build on and redirect aspects of Labour's modernization agenda. Especially in health and education, it has put pressure on public sector providers to outsource services and scrutinize terms and conditions of employment (Bach, 2012). It also portrays employment law such as the Transfer of Undertakings (Protection of Employment) regulations (TUPE), which implemented the EU Acquired Rights Directive, as a barrier to competition: 'the costs and burdens associated with TUPE regulations are frequently cited as a barrier for independent providers taking on state run services' (Cabinet Office, 2011: 44).

The government has questioned the utility of national pay determination and proposed more localism in pay rates, encouraging reductions in poorer parts of the country. An early example of coalition policies to undermine national pay determination was the abolition of the Negotiating Body that provided a national framework for careers and salaries for school support staff. The government's consultation on local pay, however, found little favour with employers or the pay review bodies, given failed experiments with local pay in the 1990s (Bach and Winchester, 1994) and the lack of evidence that public sector pay rates 'crowd out' private sector employment. Instead, the government is encouraging the abolition of seniority-based incremental progression and its replacement with performance-related pay, starting with schools (Treasury, 2012: 66).

In Ireland, austerity measures are being implemented in a context of renewed attempts to reform public services, though Ireland has been more cautious in its embrace of NPM. In a comprehensive review of Irish public services, the OECD (2008) criticized weak performance measurement and financial accountability and limited attempts to increase flexibility in employment practice. There has been unease about the state of public administration (Boyle and MacCarthaigh, 2011) and the Troika's rigid timetable for the reform of public finances has been interpreted as indicating a lack of confidence in Irish economic governance (Barrett, 2011). In November 2011, the government adopted a public service reform plan that proposed 'radically reducing our costs to drive better value for money' and 'leading, organising and working in new ways' (Department of Public Expenditure and Reform, 2011: 6).

The main focus of attention has been to meet the Troika requirements for rapid reductions in the public sector paybill. Limited public management reform and the severity of the crisis encouraged a preoccupation with short-termism, but the legacy of social partnership encouraged some engagement with trade unions. Discussions between the public sector unions and the government with employer involvement led to a four-year (2010-2014) Public Service Agreement (the Croke Park Agreement), under which it was agreed that there would be no further public sector pay cuts before 2014 and no compulsory redundancies, in exchange for phased staff reductions and a commitment to reform, including changes in work organization 
alongside the flexible use of redeployment. The Agreement included a peace clause with binding dispute resolution mechanisms. These reforms have been monitored by an implementation board that publishes annual reports on progress, supported by separate subsector groups with published action plans to ensure that employers and unions progress changes in working practices and enhanced productivity (Implementation Body, 2010). For example, 'performance management systems will be introduced in all areas of the Public Service where none currently exist' (Implementation Body, 2010: 6). The implementation reports are cautious about longer-term modernization, pointing to efficiency gains, paybill savings and staff redeployment, but also expressing the need for greater urgency (Implementation Body, 2011, 2012). It is notable that the subsequent 2013 Haddington Road agreement (see below) is more specific in relation to stronger performance management measures, 'more flexible and faster redeployment' and an explicit call for additional working hours 'to facilitate further reductions in staff numbers' (Labour Relations Commission [LRC], 2013: 11).

\section{Paybill reductions: Pay, pensions and employment}

The UK coalition government in an emergency budget in June 2010 announced a two-year wage freeze that it anticipated would save $£ 3.3$ billion by 2014-2015, and a less favourable measure of inflation for indexing pensions (Treasury, 2010a, 2010b). The Autumn 2010 spending review focused on quantitative reductions in wages and pensions and additional workforce reforms because 'the overall value of the public sector reward package, including pension provision, has been generous in recent years' (Treasury, 2010a: 37). The government viewed the public sector workforce as key beneficiaries of the previous Labour government. Consequently they assumed that public sector wage restraint would generate little public sympathy for the workforce during a severe recession.

\section{Pay restraint}

The public sector workforce is subject to at least a five-year period of pay restraint - a twoyear freeze followed by three years when awards are limited to an average of 1 percent. The initial freeze covered 2011-2012 and 2012-2013 across all areas of the public sector, with some protection for staff earning $£ 21,000$ or less (but not in local government). This exemption covered 1.7 million public sector workers (28 percent of the total) (Institute for Fiscal Studies, 2012: 111). In addition, because workers in health, local government and some parts of the civil service are currently covered by progression arrangements - annual pay increments average public sector pay is still growing in nominal (but not real) terms. The Office of Budget Responsibility estimated that public sector pay would increase by 2 percent in 2011-2012 and by 0.8 percent in 2012-2013. This growth encouraged some local employers to examine ways to exert more forceful downward pressure on the paybill by freezing wages and increments, scrutinizing other components of pay and changing the composition of the workforce.

The two year pay-freeze was first implemented in parts of the civil service in 2010-2011, reflecting the government's ability to exert direct control over the paybill despite the formal delegation of pay determination to agencies and departments. Civil service departments have 
been subject to a 1 percent pay limit for 2012-2013 and 2013-2014 but the government is seeking further paybill reductions by its commitment to end 'automatic time-served progression pay' (Treasury, 2013: 29). This indicates government commitment to use the climate of austerity as a catalyst to reduce costs by removing service-based increments and to link progression more explicitly to contribution. In addition, paybill reduction has been pursued vigorously by reducing headcount (see Table 1).

Table 1. UK public sector employment (headcount, 000s) by sector (Q1, seasonally adjusted).

Table 1. UK public sector employment (headcount, 000s) by sector (Q1, seasonally adjusted).

NHS employers have directed more attention at altering the national Agenda for Change pay agreement than reducing headcount. This reflects the more protected financial settlement for the NHS and the requirement to achieve waiting time and other service standards that are highly dependent on adequate staffing levels. Sectoral negotiations with staff representatives on changes to core conditions for NHS staff have continued; they have not been superseded by government unilateralism. Employers have questioned whether the national pay system is 'fit for purpose', proposing that increments should be more related to performance. The aim has been to reverse the gains that trade unions achieved in the Agenda for Change agreement, established in 2004 when government priorities were to address equal pay problems and boost staff earnings to deal with recruitment and retention problems (Perkins and White, 2010).

The dilemma for trade unions is that if they do not make concessions at national level, employers may implement more fundamental changes locally, possibly unilaterally, reducing both the legitimacy of national pay determination and trade union influence. A regional consortium of NHS employers put forward more radical changes than those negotiated nationally, including changing annual leave entitlement and increasing the length of the working day. This put pressure on both national employers and trade unions, and modifications to Agenda for Change were agreed and implemented during 2013. The pressure from below can also be illustrated by the case of Central Manchester University Hospitals NHS Foundation Trust. This employer imposed a new incremental pay progression policy that denied increments to staff with a poor sickness record. The unions argued that this breached the national agreement by linking pay progression to attendance. The main trade union, Unison, was successful in an employment tribunal claim and the policy was withdrawn in February 2012 (Unison, 2012).

Pressures for wage moderation have been more pronounced in Ireland, not only because of the size of the fiscal adjustment but also because of arguments that the public sector enjoyed a relative wage premium before the crisis (although comparisons need to be adjusted for the differing employee attributes of public and private sector workforces). Between 2003 and 2006 
the public sector wage premium rose substantially to 22 percent. A primary reason was a 2002 benchmarking exercise, intended to bring order to pay determination in the public sector and prevent industrial strife. Geary and Murphy (2012) suggest that the generosity of these awards reflect the political capital that government and trade unions had invested in the benchmarking and social partnership process, and also government expediency that trumped fiscal rectitude in the run-up to an election. This formed an important backdrop to the crisis, enabling governments to link fiscal crisis to excessive wage settlements.

The first measure in 2009 was the cancellation of an agreed pay increase, followed by a general reduction in pay for all public sector employees implemented from the start of 2010. Public sector pay was reduced on a sliding scale, resulting in cuts of 5-8 percent for those earning up to $€ 125,000,8$ percent for those earning up to $€ 165,000,12$ percent for those earning up to 200,000 and a cut of 15 percent for salaries above $€ 200,000$, indicating a more progressive approach to wage moderation than has occurred in the UK. Caps were also placed on maximum amounts of public sector pay and the salary of the Taoiseach (prime minister) reduced. There has been a differentiation between the impact on insiders and outsiders, and in December 2010 it was announced that new entrants to public services would be recruited onto pay scales 10 percent below those of incumbents (O’Connell, 2013; Stewart, 2011).

The Croke Park Agreement which exchanged pay stabilization until 2014 for a phased reduction in public sector staff numbers proved contentious, especially amongst workplace trade union representatives, but it provided some protection and respite from more far-reaching cuts in pay and conditions. In late 2012, however, the government reopened discussions, over a year before the Agreement was due to end, seeking a further $€ 1$ billion savings - a 7 percent cut - in the public sector paybill between 2013 and 2015. These additional demands reflected underestimates by the government and the Troika of the negative effects that austerity measures would have on economic growth, exacerbating Ireland's debt and deficit position (Erne, 2013). After trade union rejection of an earlier set of proposals in spring 2013, the government introduced legislation to cut public sector wages unilaterally. Unions could exempt themselves from the legislation if they individually endorsed modified proposals, termed the Haddington Road Agreement (LRC, 2013). The agreement included some modest government concessions (e.g. on increases in working hours) and was eventually ratified under duress by virtually all public sector unions in membership ballots. Measures in the agreement include increases in standard working time of approximately two hours per week, lengthening of time periods (linked to earnings) in receiving pay increments, and additional pay cuts of between 5.5 and 10 percent for those on annual salaries over $€ 65,000$ (LRC, 2013).

\section{Pension reform}

In both countries, governments have viewed reforms to pension provision as an important component of their ambition to 'deprivilege' public sector pay and conditions. Public sector pensions have been portrayed as overly generous and these criticisms have gained some traction with the public in both countries, in part reflecting a race to the bottom in the private sector. 
Although UK public sector pensions are more generous than in the private sector, they remain very low. In 2009-2010 the median public sector pension was around $£ 5600$ per year and the Independent Public Service Pensions Commission inquiry 'firmly rejected the claim that current public sector pensions are "gold plated"' (Hutton, 2011: 26). The government accepted its recommendations and built on these changes, in particular indexing and uprating pensions in line with a Consumer Price Index which is lower than the previous measure of inflation; aligning normal pension age with the state pension age which will move in steps from 65 to 68 by 2044/5; increasing workers' contributions with the highest earners facing the largest percentage increases; and switching from final salary to career average schemes, though with workers' accrued rights protected from any changes.

An additional complication is that there are separate pension schemes for the civil service, teachers, local government and the NHS with different financing and accrual rates. These pension reforms have created widespread anger amongst public sector workers, provoking industrial action by doctors in June 2012 for the first time since 1975. However, ambivalent public attitudes and differences between the schemes created scope for the government to open up divisions between trade unions whose members are affected in very different ways. This has been reflected in the range of outcomes in trade union membership ballots, from outright rejection to endorsement of negotiated deals. Trade unions generated considerable mobilization against pension reform during 2011, but ultimately a lengthy and complex process of schemebased negotiations led to settlement of these disputes across the public services.

Data on public sector pensions in Ireland indicate that in 2009 almost 40 percent of retired civil servants had a pension $€ 12,000$ per annum or less, whilst around 3 percent had a pension over $€ 60,000$ per annum. One of the first austerity measures adopted by government was a 'pension levy' of up to 12 percent on income above $€ 20,000$ (Stewart, 2011). Many other reforms to pension provision mirror changes in the UK, with: a phased increase in the minimum pension age initially to 66 and then linked to the state pension age that will increase to 68 in 2028; pensions to be based on career average rather than final salary; and pension increases linked to inflation rather than pay movements (European Commission, 2012).

\section{Employment reductions}

Employment reductions follow a period when UK public sector employment increased by around 15 percent over the decade up to 2009 and in Ireland the expansion was closer to 30 percent (Bach and Kessler, 2012; O'Connell, 2013). The current UK reductions, however, are unprecedented in their severity. The majority of redundancies have occurred on a voluntary basis or by the use of early retirement schemes, but mandatory redundancies have been implemented, traditionally a very rare occurrence in the public sector. The Office of Budget Responsibility predicted in June 2010 that public sector employment would decline by 490,000 jobs by 2014-2015 but this forecast has been increased several times and it is expected that in excess of 730,000 jobs, around 13 percent of general government employment, will be removed by 2016-2017 (Office of Budget Responsibility, 2012). As Table 1 indicates, between 2008 and 2013 the public sector shrunk by around 5 percent but this is effectively an underestimate 
because of the inclusion of public corporation employment (including banks taken into public ownership after 2008). Job losses were in excess of 14 percent in the civil service and local government during this period.

In the case of the civil service, the Conservative-led government, without prior consultation, announced the abolition or merger of 262 government organizations in its 'bonfire of the quangos'. The intention was to save $£ 2.6$ billion but this figure has been disputed (National Audit Office, 2012). In addition the government implemented a recruitment freeze on permanent civil servants and resorted to fixed-term appointments and temporary staff, alongside a moratorium on employing consultants. The Public Accounts Committee reported that central government departments had reduced headcount by around 35,000 at an estimated cost of $£ 600$ million in 2011, but with potential annual savings of $£ 400$ million by 2013 . However, it expressed concerns that 'Given the scale and pace of headcount reduction and the lack of business redesign in departments, there are significant risks to service delivery' (Public Accounts Committee, 2012: 5).

NHS employment reductions have been much less pronounced, although individual NHS trusts have been engaged in a continuous process of mergers and restructuring that have included voluntary redundancies or severance programmes. The complexity of the NHS workforce has encouraged NHS employers to examine the skill-mix of their workforce. Responses from over 34,000 NHS trade union members during 2012 indicated that in their workplace the most common responses to financial challenges were restructuring services, recruitment freezes and reductions in posts, cited by around 60 percent of respondents. A major concern amongst members is the increase in 'downbanding', reductions in the grades of posts following service reconfiguration. Overall, NHS staff report increased workloads, staff shortages and lower morale (Staff Side, 2012).

In Ireland, employment reductions have also been achieved predominantly on a voluntary basis, with incentives provided to make this attractive. As Table 2 indicates, between 2008 and 2013 public sector employment was reduced by about 8 percent. The data for health overstates the size of its decline substantially because it includes the transfer of staff into the civil service.

Table 2. Public sector employment in Ireland (headcount) by sector $(\mathrm{Q} 1)$.

Table 2. Public sector employment in Ireland (headcount) by sector (Q1).

\section{Social partnership and trade union prospects}

One of the main outcomes of fiscal consolidation programmes has been a marked reduction in the influence of public sector trade unions and an associated depletion in the role of social 
partnership within public services, but it has taken different forms in each country. These developments are of great significance for the overall vitality of the labour movement, because trade union membership is disproportionately concentrated in public services with density three to four times higher than in the private sector in both countries (Bordogna and Pedersini, 2013).

In the UK, there was no prior consultation with employers or trade unions prior to the 2010 announcement of the wage freeze, and key decisions about pay policy have been decided unilaterally by government and announced in parliament as integral components of fiscal retrenchment rather than forming part of longstanding industrial relations negotiations. Trade unions have expressed forceful opposition to austerity because it is viewed as having malign effects on economic growth and employment, transfers the responsibility of adjustment for the crisis from the financial sector to the public service workforce, and is being used to accelerate a neoliberal agenda of privatization (PCS, 2011). It is suggested, however, that trade unions have failed to develop a compelling alternative to cuts (Nolan, 2011); the preoccupation has been with opposing immediate threats to members' terms and conditions. The opportunity to link cuts in staffing and employment conditions to a narrative focused on outcomes for service users in terms of the implications for safety, quality of service, accessibility and equity has in the main not been pursued effectively. A partial exception is work undertaken by unions representing professionals, which have responded to membership concerns about maintaining professional standards in a context of budget cuts. In 2011, the Royal College of Nursing congress voted in favour of legally enforceable staff levels to safeguard patient care (RCN, 2012). Prospect, which represents public sector professionals, has developed an alternative vision for the civil service that advocates reform but based on high standards of professionalism (Prospect, 2012).

In the absence of any meaningful dialogue with government, the main response has been concession bargaining at sectoral and workplace level, and some set-piece industrial action. In 2011, a series of one-day strikes culminated in coordinated action amongst 30 trade unions, with the participation of up to two million workers from the NHS, civil service, schools and local authorities (Hall, 2012). This spike in public service industrial action, however, has not continued in 2012 and 2013. Public service trade union influence continues to wane for four main reasons. First, there are the longstanding legal obstacles to industrial action in the UK, with unions only protected from being sued if the dispute is a legal trade dispute with their members' employer. Consequently, a general strike would be deemed unlawful, and attempts to mobilize against the government require an individual mandate from each union's membership and then coordinated action between unions on the same day - a very complex political and logistical challenge.

Second, public service trade unions acknowledge that their members' are very fearful of industrial action. In a climate of staffing reductions, declining union density and squeezed living standards there is a reticence about taking action that will result in a loss of income and which may have little impact on the employer. These sentiments have been reflected in relatively low turnouts for industrial action and unconvincing majorities in ballots. Third, there is a degree of acceptance amongst public service union members that fiscal consolidation is 
necessary and this recognition is combined with considerable doubts about the extent to which trade unions can alter government policy; none of the anticipated further industrial action over pensions or more generalized calls for mobilization, such as at the 2012 TUC congress, has materialized. Finally, public service trade unions confront difficulties in securing sufficient workplace representatives to build workplace union organization and develop a collective sense of grievance against employers.

In Ireland the escalating economic crisis precipitated a breakdown in social partnership in 2008-2009 and the number of workers involved in industrial disputes increased from 356 to 278,000 in 2009 , mainly through a series of one-day public sector strikes, before declining to 511 in 2010 following the Croke Park agreement (Spotlight, 2011: 5). The Agreement therefore proved effective in dampening down industrial action in the public sector by recalibrating the legacy of social partnership. For critics, it is this very tradition of social partnership that has demobilized protest by incorporating trade unions into policies of austerity and creating topdown rather than bottom-up mobilization strategies (Allen, 2012; McDonough and Dundon, 2010). Protest has continued but in different forms such as a boycott of new household charges, but as in the UK industrial action has been very limited because there is widespread fear of job loss. The comments by the recipient of the 2012 Secondary School Teacher of the Year Award illustrate these fears. She highlighted work intensification and the impact of teacher redeployment on non-permanent teachers: 'if you are wondering why non-permanent teachers aren't screaming about this from the rooftops - the simple answer is because we are afraid... if we make ourselves visible we might lose our jobs' (O'Connor, cited in Kerrigan, 2012: 217).

Thus it is misleading to view the Croke Park Agreement, and even more so its successor the Haddington Road Agreement, as representing a revival of social partnership despite this legacy being an important influence on their negotiation. First, they only apply to the public sector rather than the whole economy and this has opened up divisions between the public and private sectors, limiting scope for joint action and reinforcing the portrayal of the public sector as privileged producer interests that require urgent reform. As the Minister of State noted, 'there has been far too much populist, ill-informed commentary about the Croke Park Agreement in particular. This had the effect of creating divisions between the private sector and those working in the public service' (Hayes, 2012: 13). Second, these agreements represent a framework for implementing government cuts in employment and changes in working practices that had already been decided prior to any discussions with the trade unions. Had they refused to participate they risked being publicly censured in a volatile economic and political context, or as in the case of the Haddington Road Agreement face even more severe wage cuts. Consequently, despite considerable unease, in June 2010 the Irish Congress of Trade Unions Public Services Committee endorsed the Croke Park Agreement. Commitments on job security and no further pay cuts were conditional on achieving savings; a very different form of exchange from the social partner agreements of the 1990s.

Nonetheless, these agreements provide some safeguards to forestall even deeper cuts, and transparency about the process of fiscal consolidation. An illustration of this process occurred during 2012 when the Health Service Executive targeted overtime, allowances and premium 
pay to generate additional savings. These measures were opposed by the unions because they argued this represented a cut in core pay and therefore breached the agreement, resulting in a referral to the LRC. This indicates that the Croke Park Agreement placed a brake on unilateral change and provided some respite from more far-reaching cuts in pay and conditions, albeit only until 2013. The Implementation Body (2012) reported that sustainable paybill savings of $€ 810$ million had been achieved during 2010-2012 by staff reductions, reduced overtime, rostering changes and rationalization. The cumulative impact of austerity measures is that the total net public service paybill is expected to reduce by $€ 3.3$ billion between 2009 and 2015, a decline of around 20 percent.

\section{Conclusions}

The UK and Ireland are frequently classified as liberal market economies, with limited scope for the institutionalized representation of employee interests in contrast to coordinated market economies. More recently, it has been recognized that there are variations within the liberal market category. Ireland illustrates these variations with a legacy of social partnership even though few of the institutional preconditions for social partnership appeared to be present. It could be anticipated that austerity measures implemented in a period of economic crisis with economic sovereignty curtailed (as in the case of Ireland) would leave little scope for social partnership and workforce engagement. These expectations have mainly been confirmed, but in Ireland (unlike the UK) a lingering commitment by government to engage with trade unions remained, reflected in the preference for collective agreements to implement austerity measures rather than reliance on government unilateralism. In the UK the shallow legacy of social partnership bequeathed by New Labour was also in more marked retreat, with the imposition of pay freezes by government, although trade unions and employers continued to seek sectoral collective agreements on issues such as pension reform.

Since 2008, Ireland has faced an unprecedented crisis and deep expenditure cuts after a decade of public sector employment and wages growth. Social partnership arrangements implemented in a different economic and political context could not realistically bear the level of cuts required, but this pre-existing legacy did encourage the government to seek legitimation from the trade union movement, and all parties were anxious to avoid sustained industrial action. The Croke Park Agreement and even more the Haddington Road Agreement did not indicate a revival of social partnership, but signified government attempts to manage austerity measures in an orderly manner to demonstrate to the Troika that Ireland was in Allen's (2012) phrase a 'model pupil'. Public sector unions were able to temper fiscal consolidation for existing workforce insiders by providing a measure of employment security, negotiating relatively favourable severance packages, and shifting some of the burden of adjustment onto temporary workers and new entrants. At the same time there has been a deterioration in working conditions, including the extension of working hours. Paradoxically, what Geary and Murphy (2012) term the 'weight of invested capital' in social partnership facilitated favourable public sector pay and employment growth in the Celtic tiger years, undermining subsequent scope for widespread mobilization against austerity. The blunt message to the public sector workforce in Ireland, but also in more dilute form in the UK, has been that the good times are over and the 
public sector workforce is expected to accept the prescribed medicine of pay and employment reductions.

In the UK the dynamics of austerity have been different. The coalition government confronted less immediate external pressure to reduce public expenditure, but it has a more explicit ideological predilection for a smaller state. It also highlighted the sustained growth in public sector pay and employment in the previous decade and responded by promoting further liberalization of the public sector. It deepened and extended Labour government reforms that encouraged an increased role for the private sector and more competition between a range of providers, presided over by a cadre of dominant managers, subject to comprehensive systems of performance management. Shallow systems of social partnership were easily set aside as employers have been tasked with making large paybill savings in a compressed time period. These measures have been legitimized by emphasizing the need for fiscal rebalancing, suggesting that under the Labour government public sector employment and wages became bloated. Public sector unions have always relied on political pressure and public support, backed up by membership willingness to act, to advance their interests. These conditions have been in short supply in an era of austerity.

The process of implementing austerity measures has therefore differed but the measures and consequences have shown less variation. The main form of adjustment has been substantial cuts in employment and pay. In the UK, employment reduction has been the most important element in fiscal consolidation, most evidently in the civil service and local government. Pay has been moderated but employers and the government have sought more substantial cuts by challenging incremental pay progression, cutting allowances and reviewing starting salaries. In Ireland, employment has also been reduced substantially but pay cuts have been a more prominent form of adjustment and there has been similar interest in strengthening performance management and ensuring that pay progression is more tightly aligned to performance. In both countries therefore, the attempt to restore a particular Anglo-Saxon finance-led growth model has targeted the public sector workforce and the influence of public sector trade unions has diminished substantially. Public sector unions have been forced into forms of concession bargaining and the reaction of union members has been muted, reflected in very limited industrial action. The risk is that when economic growth returns the public sector in both countries will appear far less attractive places to work than in the past, and this could seriously jeopardize efforts to recruit and retain a talented workforce that will help deliver high quality public services that maintain competitiveness and social cohesion.

\section{Funding}

This research received no specific grant from any funding agency in the public, commercial, or not-for-profit sectors. 